\title{
Authentic living and resource control in Africa: the experience of the Niger delta region of Nigeria
}

\author{
Ncha Gabriel Bubu and Mary Egbai \\ Lecturer - Philosophy Department, University of Calabar, Calabar
}

\begin{abstract}
The people of the Niger Delta have been in turmoil over the years, since the discovery of oil in that area in 1956. And since the indigenous government took over the oil rich land through its foreign agents the multinational companies, there has been serious agitations by the civil right and environmental activists against this occupation that has caused untold hardship to the people through the degradation of the environment in terms of oil spillages and pollution. Consequently, the non-challant posture of the Nigerian federal government over this situation had driven most people into inauthentic existence, hence the issue of militancy in the region arose from here. This paper examines these issues while submitting that authentic living as an existential imperative could be a solution to the lingering crisis in the Niger Delta, and the thrust of this paper is that Jean Paul Sartre's existentialism becomes the panacea to authentic existence.
\end{abstract}

Key terms: Niger Delta, Resource control, authentic living, Existentialism.

\section{INTRODUCTION}

The issue of resource control in Africa has a long history. The struggle for resource control, according to some analysts, could be the result of lack of or abundance of such. A typical example of such abundance is Nigeria, with its vast natural resources, yet embroiled in the oil war with its citizens in that region. The Liberian and Sierra Leonean civil wars are largely attributed to the struggle for natural resources. Charles Taylor, is on trial at the international court of justice for alleged trading with illegal diamonds to prosecute war.

Such countries as the Republics of Northern and Southern Sudan are in conflict over the oil rich Abiya region at the border line between the two countries, a case of limited resources. Zimbabwe's President, Robert Mugabe's seizure of land from white farmers, for the indigenous farmers, is perceived as an action fueled by inadequacy. The same struggle could be seen in democratic Republic of Congo. While lack of resources could be the reason behind the conflicts in Niger, Tunisia, Guinea Conakry among others.

However, collier (2000), sees resource conflicts called new wars, as part of the contest by both internal and external actions for resources, which is fuel in hand by abundance and in the other hand scarcity as the main economic factors associated with conflicts (Kaldor, 2001). One argument is that resource conflicts are caused by foreign interest with mercantilist and imperialistic intentions explains the marriage between resource and conflict in global history. Prof. Eskor Toyo, (2007) Lends credence to this when he says that globalization, is an aspect of West European mercantilism and expansions designed to dominate the design made by private circles seeking great wealth and power, with states acting in their support. In the same vein, Paasewe, (2003), says "the network of tactics and stratagems by which big, powerful and wealthy countries contrive to dominate Africa without necessarily reverting to direct armed conquest or land grabbing is becoming more vicious and grindingly cruel". Following the above, the overall effect of this situation is an alarming increase in regional crisis. For Oshita (2007). The regional crisis in Liberia, Sierra Leone, DRC, Angola and Mozambique, Ivory Coast, Sudan, could be traced in part to the fact that most African states depend on primary commodities, e.g crude oil, gold, diamond, etc for which foreign interests with the industrial capacities compete for concessions from the seeking regimes, intensifying the conflict for their possession.

In this paper, I shall discuss the issue of resource control in the Niger Delta, its attendant consequences of inauthentic existence leading to various forms of social vices and the need to existentialize this problem through authentic existence or living.

Niger Delta: The Niger Delta region is located in the southern part of Nigeria. It is found in the area called South-south geographical zone of Nigeria. There are 
a number of ethnic nationalities occupying this vast land. These ethnic nationalities include ljaw, Orhobo, Isoko, Ndokwa, Ogoni, Andoni, Ibibio, Ibeno, Eket, Orons, Kalabari, Etche, Ikwere, Ogba, Itsekiri, Efik (Okoh, 2007).

The Niger Delta, is blessed with abundant natural resources, specifically crude oil deposits found in onand-off shore. Analysts say that the discovery of oil since 1956 in Oloibiri community in Ogbia local government of Bayelsa state, has been a blessing and a curse on the inhabitants. Some say it is more of a curse than blessing. This means that oil, which happens to be the mainstay of the Nigerian economy, ironically has caused more harm than good to the people from whose land it is mined.

What has come to be known as the Niger Delta problem originated from this. The problem has to do with the dissatisfaction of the people with the oil exploration activities in that region, which has caused untold hardship to the people in terms of underdevelopment, unemployment, environmental degradation, palpably pervasive poverty, exclusion from mainstream political participation etc. The attempt by the people to resist this total disregard of the impact of ecological degradation has often landed them in serious conflict with the government who also wants to maintain its, arguably, legal authority over the resources. Thus, tension, fear, and uneasiness loom largely in the region as a consequence.

Resource Control: Natural resources as important as they are, are not evenly distributed. This uneven distribution by nature usually forms the cause of conflict among the citizens of such society or societies. A factor that often encourages this crisis is government's desire to control, explore, and exploit such resources. However, those in whose land such resources are domiciled consider such action by government as an incursion into their natural right of ownership, especially where compensations are not paid for such resources so extracted or mined.

Following this, a misunderstanding between the parties involved, could trigger a conflict of serious dimension. So, we can say that resource control could be the wish, and desire to control what resources and by who. It denotes the effort or agitation for the total control or absolute autonomy over the natural endowments within their territories. As Egbe, and Ihejiamaizu (2001) put it, it is the demand for power and authority to order, direct, and restrain the exploitation, allocation and distribution of these resources. The famous playwright Ken-Saro
Wiwa, and eight of his kins men were extra judicially killed for this struggle.

Existentialism: This refers to the school of philosophy or a philosophical movement that emerged in the $19^{\text {th }}$ century in continental Europe. It is seen as a movement or revolt against traditional philosophy in its method and concern. Simply, existentialism is a movement that believes in subjective choosing over objective reasoning, concrete experience over intellectual abstractions, individuality over mass culture, human freedom over determinism, and authentic living over in-authenticity (Lawhead, 2003).

Thus, existentialism emphasizes the uniqueness and freedom of individual person and argues that each person must take full responsibility for his own existence and to create himself. As a philosophical school of thought or movement, it is concerned with man as a being subsumed in existential complexities.

Sartre's existentialism is a strand of existentialism peculiar to Jean-Paul Sartre. Authenticity is one of the terms in existentialism, and in Sartre's existentialism, it denotes a kind of living that is responsible, honest, sincere and devoid of bad faith, self deception and injustice.

\section{Authentic living and Resource control}

The issue of resource control in the Niger Delta region and other areas in Nigeria, could be traced to the colonial attempt at building Nigeria, which may be called an arrangement of discordant and diverse elements into a whole that is now described by many as a geographical expression, far removed from the trappings of a nation. Ucheaga, in a paper on "Sustainable Development and the Ethnic minority in Nigeria Question" explains that the political patch work called Nigeria lies at the basis of the minority question in Nigeria which is a product of ethnic rivalry. According to her:

The political entity known as Nigeria was a forced union of antagonistic and heterogeneous nationalities forged by the British imperialists to facilitate economic and political control. This was effectuated in 1914 through the instrumentality of amalgamation of the 
northern and southern protectorates. (2009)

It is imperative to point out that the British colonial administration provided a fertile ground from which most Nigeria's problems germinated. One possible reason for this unfortunate scenario is that the country was founded on a poorly misconceived architectural design rested on a wobbly foundation laced with ethnic and primordial materials and fostered by inept leadership and corruptive attitudes that pervade the political environment of Nigeria. As such achieving economic and political progress and national unity becomes and uphill task. (Ncha, 2010).

Precisely, it was Arthur Richard's constitution of 1946 that brought Revenue allocation in Nigeria so, he could be regarded as the progenitor of revenue allocation in Nigeria. The issue of resource control emanates from here as one of the problems of revenue allocation.

The formula and procedure for revenue allocation based on the principle of fiscal federalism, is fundamental as it has a strong affinity with the power distribution system among the component units in Nigeria. This system, constitute a source of complaints from the ethnic minorities especially the southern minorities who are not favoured by the distribution. At the centre of this controversy is the "Derivative principle" which says that a significant proportion of the revenue collected in a locality should be returned to the locality or segment.

The principle was introduced at a point in Nigeria's history, when cocoa, groundnut, and other cash crops generated foreign income earnings. These were commodities produced by the majority groups. At this point, the derivative principle was seen as the most equitable and efficient method of sharing federally collected revenue. It is saddening to mention that this same derivative principle was later employed as a tool to oppress, suppress, and dominate the minorities.

One can discern from the above that the resource control issue is inextricably linked to the issue of minority because, their circumstances as minorities make it easy for them to be victims of ill-conceived policies that infringe on their rights. So, the logic of the minorities is anchored on the fact that prior to the emergence of cocoa, groundnut, and other cash crops, the issue of derivation was non-existent presumably because funds for the maintenance of the country were being raised from products, especially palm oil from the east. The issue of derivation however, made a sudden entrance and assumed an important position in Nigeria's politics. This happened essentially because it put the majority in a vantage position, when their agricultural products were no more useful in revenue generation.

However, the derivative principle, as important as it was by the calculation of the majorities, began dwindling in its prominence at a point when it no longer favoured the majority ethnic groups. The above position is captured when Eme, (2002). Quoted the report of the political bureau of March, 1987, as saying that:

The British financed the
administration of the
country namely with
proceeds from oil palm
derived largely from
eastern region at that time,
basing allocation of
revenue mainly on
derivation was not given
serious consideration.
However, with the creasing
importance of groundnuts
and tin (from the north) and
cocoa and rubber from the
west, derivation was
catapulted into a major
criterion for allocation.

This explains that from the onset, the system of administration in Nigeria has always favoured the majority ethnic groups to the detriment of the minorities. The revenue allocation issue is a highly politicized matter and has been manipulated as an instrument for denying the minorities of what rightly belongs to them. If not, what reasons can one adduce for the progressive reduction in derivation quota when we recalled that the present $13 \%$ fell fatally from 50 percent recommended by the various revenue commissions during the colonial era with the Phillipson commission blazing the trail.

It is on this note that oil producing states, are demanding to know the logic and rationale for the attachment of so much importance on mineral resources, with particular emphasis on petroleum resources as it concerns the derivation principle. It must be mentioned that the inequality in the aforementioned system of distribution, triggered off resource control agitations in the Niger Delta.

However, the idea of resource control is not a recent development. There are recorded mild agitations in 
the past. Mild because, if juxtaposed with what we have now, amounts to a tip of the iceberg. According to Ihejiamaizu, and Egbe (2001), agitations for resource control started as far back as 1966. One Isaac Adoka Boro of the "Niger Delta Volunteer Force" organized a 12-day uprising against the Eastern Regional Government of Michael Okpara, to conscientise and sensitize people on resource control. The importance of Isaac Boro to the resource control struggle is worth mentioning here, because it shows that as far back as 1966, agitations for resource control had started. This shows in a way that the people have suffered neglect for too long, and also shows the importance of Boro, as one of the vanguards of resource control. As far as resource control is concerned, he remains a key factor in the struggle.

For Udeme Ekpo (2004), agitations for resource control with its attendants problems currently plaguing the inhabitants in the Niger Delta, snowballed from demands for a fair share of the national cake to the right to have control over natural resources that are found in the area soon after the fourth republic. This development in the view of some observers, has its ideological anchorage on the struggles of the Ogoni people usually under the banner of (MOSOP) movement for the emancipation of the Ogoni people. Mosop is seen as the first to pose the question of resource control in respect of equitable benefits from oil explorations in their land.

Whatever the level of agitation now, it is attributed to the emergence of commercial oil production from the region in 1958 which raised the stakes and generated a struggle by the indigenes for control of oil resources (Ikelegbe, 2005).

For William, (2002) historically, the occurrence of conflict over access and control of oil resources in the Niger Delta can be traced to the inherent contradictions that exist in Nigeria's federal set up.

Basically, the explosive situation in the Delta region rests on may be three major factors namely: the attitude or non-challant posture of government, the imbalances in the federal set up, and the condition of the Niger Delta. The first factor has a direct link to the second one. This is so because the attitude of the federal government that has been mostly in the hands of the northerners since independence indicates a lack of interest in the plight of the Niger Delta, and support for anachronistic system that facvours the northerners to the detriment of the southern minorities, an obvious contradiction of the spirit of federalism. This may be why Ikelegble, writes "The northern hegemony taking advantage or military dictatorship began a regime of near total appropriation of the region's oil resources through an intense centralization and concentration of power and resources in the federal government".

The second factor which is the imbalance in the federal arrangement is nurtured by the federal power brokers to ensure monopoly and undue advantage. The major targets here were oil resources. The manipulation is usually carried out through obnoxious laws and decrees. For instance, such laws as the petroleum control decree of 1967. The oil in Navigable water Act of 1968; mineral oil safety regulations law No 45 of 1968 and oil Terminal Dues Act of 1969. Others are the petroleum Act of 1969, Land use Act of 1978; Exclusive Economic zone Act of 1978; Land Title vesting Decree of 1993 and the National inland water ways authority Decree of Decree of 1997, were meant to confiscate land from the people (Ncha, 2010)

The third factor, is the consequence of the other two mentioned above. That is, the deplorable and unhealthy, and pathetic situation of the Niger Delta, results from the combination of the factors enumerated above. This is described in terms of underdevelopment, ecological crisis, the ravaging effect of oil exploration: destroyed roads, rural farming, fishing and hurting ventures are stiffed, resulting in unemployment youth restiveness. For some, bad governance explains why there are incessant conflicts in the region, while others say it is a class structure that is corrupt and has a voracious grip on the national coffers. William sees it as the result of a systematic, calculated and structured sense of political, economic, and social exclusion of groups in the distribution and share of national advantages and privileges. In line with William, Idowu (1999), opined that this class dominance is made possible through what he calls an overriding power philosophy. This wrong philosophy enables the dominant, alienating group to define citizenship status as that of first class citizens and others to a set of second class citizens within the same geographical boundary.

The concept of an overriding power philosophy denotes a philosophy, which uses power as a determining factor in allocation of resources and which sets the criterion and qualification for such distribution which is not based on the principles of distributive justice I share this view of Idowo, because such power philosophy is wrong and does not bring 
into perspective, the peculiar circumstances of the individual, but is heavily whimsical in its approach to issues no matter how contentions. Besides, this overriding power philosophy is meant to protect the interest of a few who do not recognize the humanity of the other, so long as the manipulated situation goes on to dish out undue advantages to them.

While one may toe the line of the views above, it is germane to point out that this paper argues that, it is not just the presence of this overriding philosophy, but the lack of an existential philosophy or justice, which has culminated in the unwholesome attitude of the power brokers in Nigeria, resulting in their inauthentic living, hence the need to bring in authentic living and usher in the Sartrean existential philosophy that is proactive, practical, pragmatic and truthful. This is the concern of this paper.

This paper further argues that inauthentic living is the bane of the Niger Delta crisis, and that authentic living can curb the resource control problem. Problems usually issue from the sharing formula seen by many particularly those from the oil producing region as grossly lopsided and smacks of unfairness, injustice and a denial of what properly belongs to them as their natural right of ownership. Besides, the process of extracting these mineral resources, has not been fair and friendly to the people and environment, thus exposing them to an avalanche of ecological and environmental problems and a hostile and militarized atmosphere.

The above preamble forms the basis of the idea of resource control. Resource control actually refers to the desire to control what resources and by who. The clash of interests arising from the scenario, has brought untold hardship to the Niger Delta region as a consequence of the present arrangement where the federal government takes a large chunk of the proceeds and only dish out a negligible amount to the region. This shows that a large chunk of the oil revenue accruing from the Niger Delta goes into few hands while those from whose land such is extracted are left on the edge. Maduekwe (2003) explains this "the problem of Nigeria is not the availability of resources but a pervasive and prebendal ideology which ensured that the nation's resources ended up in few hands. The issue of the marginalization of the minorities, emanates from such situation described above. The reason is that prebendalism flourishes most in an ethnic society like Nigeria. This element according to Egbe, determines the allocation of public goods in Nigeria, and is responsible for ethnic chauvinism, corruption and marginalization of unfortunate individuals and groups in the nation. In analysis of the issue of resource control, we discovered that the problem seems to have survived attempts at solving it, and has assumed crisis dimension. This is so because, the current and past management strategies of the government have been premised on theoretical, political and scientific frameworks, that do not take cognizance of the basic facts of life, the fundamental and concrete realities of the region in question. Various measures taken by the government to resolve the problem only show the in-authenticity in the approaches. It is on the strength of this that Jean-Paul Sartre's philosophy becomes relevant in solving this problem.

There are certain terms in Sartre's existentialism that can be used to address the thematic issues in the Niger Delta. In this case, we have positive terms and negative terms. The positive terms are the terms that must apply in a situation at any given time and shows the necessity of such terms, while the negative terms are the ones that must be avoided if we must solve any crisis, problem or misunderstanding in our daily lives. The positive terms include: commitment, responsibility, fundamental choice, freedom, decision, subjective understanding, constant appraisal of a situation, consciousness of self and environment, authenticity. The negative negative terms include: self deception, bad faith, avoidance of decision, postponement of decision, in-authenticity etc. These terms are determined by human facticity and transcendence which is the root of our freedom.

So, in a situation where the positive terms are applied, the individual is said to be living authentically. This is so because an authentic life is one in which the terms above characterized it. It involves free choice and the attendant responsibility. On the contrary, when an individual in any situation avoids the positive terms, and the negative terms are discernible, then such is involved in inauthentic living. This involves doing things because other do so or simply following the crowd without being subjectively conscious of one's choices and their consequences or deliberately refusing to own up to the situation that one enters into or doing things simply from a customary point of view.

It is the candid submission of this paper that the attitude of the federal government all this while, smacks of in-authenticity and therefore, lies at the base of the resource control problem in the Niger Delta. This is discernible from the various government failed attempts to find a solution. The government actions and measures have been that of 
self-deception, of playing roles, of disguising its real intention, of bad-faith and eventually indulging in inauthenticity.

From Sartrean perspective, the government has refused to recognize the burden of its freedom and the responsibility that accompanies its freedom and responsibility that accompanies its choices as it concerns the Niger Delta. In this way, the government dodges the concrete realities by pretending to be ignorant of the real situation, besides attempting to apportion blame to others in a bid to get itself free from the consequences of its freedom. This is what Sartre calls self-deception, which is seen in the mere objective rationalization of its actions instead of a subjective, thorough going appraisal of the issues involved in resource control. This has also led the government into "bad faith" an aspect of in-authentic living through avoidance of making a fundamental decision by postponement of key decision that could bring a lasting solution to the problem. One recalls that the government avoidance of a fundamental choice led to the setting up of the various committees and boards as measures towards resolving the problems. Such committee and boards as Henry Willinks of 1958, the justice Alfa Belgore judicial commission of inquiry of 1992, the Niger Delta Development commission. Others include: Don Etiebet Report of 1994; Vision 2010 Report of 1996, United Nations special Rapporteur on Human Rights situation in Nigeria of 1997, Popoola Report of 1988; Ogomudia Report of 2001; white paper Report of the presidential panel on National security 2003; Report on the first international conference on sustainable development of the Niger Delta NDDC, and United Nations Development Project (UNDP) of 2003; the Niger Delta Regional Master plan 2004, the National political conference Report 2005, the UNDP - Niger Delta Human Development Report 2006; and the Report of the technical committee on the Niger Delta of November 2008 (Tell, March 16, 2009 P. 20).

In all we can have about 15 Reports as measures initiated in order to solve the Niger Delta problem. An assessment of these report would reveal that the core recommendations of these reports suffered the same fate of non-implementation. This again shows the customary attitude of Nigerian government of non-subjective approach to issues, and an attitude of drifting along with the crowd. This behaviour has caused what I may call a multiplicity of in-authenticity in the Niger Delta. Following this, the vitiated atmosphere has driven many to indulging in various inauthentic means of survival-robbery, kidnappings, killings and other vices. In all, post-ponement and avoidance of decision is responsible for the lukewarm attitude of the government towards the reports recommendations, thus perpetrating the crisis, while the government takes undue advantage and unleash terror on the defenceless Niger Deltans.

It could be said that the use of force denotes an extreme case of deception and in-authenticity, since it only shows pretence and feigning of ignorance of the realities on the ground from the government. The approach of force is deceptive and a show of "bad faith" in Sartrean understanding because, such avoids making real choice. Sartre submits that, freedom consisted in frankly confronting the situation into which one had deliberately entered and accepting all the responsibilities. This may be why Ucheaga, (2009) sees this approach as wrong and diversionary. She says:

$$
\begin{aligned}
& \text { Indeed, the policy of } \\
& \text { equipping the armed forces } \\
& \text { well may be necessary and } \\
& \text { useful because the state } \\
& \text { has the responsibility of } \\
& \text { maintaining order and } \\
& \text { security. } \\
& \text { fundamentally, But } \\
& \text { repressive approach, if } \\
& \text { examined in the context of } \\
& \text { the minorities, appears to } \\
& \text { be the wrong approach. } \\
& \text { This is to the extent that } \\
& \text { the measures are directed } \\
& \text { at treating the symptoms } \\
& \text { rather than the substantive } \\
& \text { causes. }
\end{aligned}
$$

She went further to observe that the perpetuation of the crisis situation in the Niger Delta region, is the direct consequence of the diverse socio-economic conditions occasioned by the oil exploration activities, exploitations and corruption have visited on the people of the region. These are the very issues that are neglected by the government, issues ironically created by the very government engaging in a show of self-deception.

The Sartrean Solution: From the analysis above, it is obvious that the underlying philosophy of government is a wrong one and cannot be useful in settling disputes and conflicts in a society. Therefore, for us to resolve the resource control problem, we must give room to the Sartrean existentialist's 
philosophy which the essential aspects were mentioned above. Sartre's philosophy is a humanism geared towards tackling human problems. It is seen as a movement that encourages action and commitment, one that defines man by his action and transcendence, because, according to Sartre, only in action is there any reality. Humanity, therefore, according to Sartre, is only a sum of actions and purposes. (Sartre, existentialism is a humanism). Action takes place within the human condition, and as such one is obliged to act in a situation, that is in relation to others. So, it does matter what one does or how we choose, and as a result one's actions must not be capricious since the burden of responsibility rests on us.

It is argued that the actions of the government as it concerns the Niger Delta and resource control, do not reflect this Sartrean injunction because its devastating effects are better imagined than described. Consciousness of the environment, which is the human condition, is relevant in Sartre's philosophy and this is the bone of contention in the Niger Delta. Given that there is mutual interaction of man and his concrete environment, Sartre sues for a sustained relationship that is constantly appraised, reappraised, reinvigorated and redefined for a useful existence through sincerity, action and commitment. This for Sartre, would ensure authentic living.

Therefore, changing the situation requires personal understanding and commitment and that social consciousness comes with responsibilities. The demand for resource control is a call for change and a mark of existential philosophy which is am approach for reinventing man through repositioning by embracing the bottom line issues. This is going back to the things themselves as Hursserl would say (Hursserl, 1969), which also could be traced back to the ancient period of philosophy as protagoras echoes. "Man is the measure of all things, of the things that are that they are, and of things that are not that they are not". Government and all stakeholders in this issue must recognize this need to employ this philosophy and negate the old ways of drifting along with the crowd.

According to Sartre, avoiding the bottom line issues amounts to avoiding responsibility which is "bad faith" and indication of inauthentic living. Sartre's existentialism frowns at exploitation of the individual, for this act suppresses the possibilities inherent in the "being-for-itself", one of the divisions of "being" in Sartre's existentialism, and this leads to false hood and inauthentic existence. It is the contention of this paper that if these salient features of Sartre's philosophy are strictly applied to the resource control issues, the problem can receive a long lasting solution.

So far, we have been talking about authentic living and resource control in the Niger Delta region of Nigeria in West Africa. In our analysis, it was discovered that the problem could be solved using an existential approach peculiar to Jean Paul Sartre. It is seen that using Sartre's philosophy, the stakeholders in the Niger Delta could see existentialism as the living philosophy.

It is argued from the point of Sartre's existentialism that Nigeria should be subjectively conscious of the facts of her problems around the Delta region, and responds aggressively towards ameliorating the plight of the people. Sartre's existentialism is all about responsibility consciousness and recognition of the individual subjective existential situation, and a humanistic philosophy that recognizes the individual within a given concrete existential situation, a philosophy that sees the need for individual salvation in a crumbling world. This would lead to authentic existence and subsequently end the problem of resource control.

\section{REFERENCES}

Anayochukwu, Agbo. Still Suffering the Pangs of Labour. Tell Magazine, March 16, 2009.

Augustine, Ikelegbe. The Economy of Conflict in the Oil Rich Niger Delta Region of Nigeria. Nordic Journal of African Studies 14, No 2, 2005. P. 208-234.

Collier, Paul (2000) "Doing well out of War: An economic perspective" in Greed and Grievance: Economic Agenda in Civil Wars. Bendal, M. \& Malone (eds.), Lynne Reiner.

Eme, Iro. (2002) Politics for Non-Politicians. Calabar: Trandon Publishers.

Endmond, Hursserl (1969) Ideas: General Introduction to pure Phenomenology. Trans. By W. R. Boyce Goibson. London: George Allen and Union.

Eskor, Toyo (2007), Globalization for a perspective relevant to Africa. Calabar: Confident options. 
Ihejiamaizu, C. and Egbe B (1999), The Sociology of Traditional and Modern Political Administrative Systems and some contentions Issues in Contemporary Nigeria. Calabar: African Scholars Publishing.

Kaldor, Mary (2001), Old and New Wars: Organized Violence in a Global Era, Cambridge: Polity Press.

Lawhead, William F. (2003) The Philosophical Journey: An interactive Approach. New York McGraw-Hill Companies.

Maduekwe, Ojo (2003) Understanding the PDP Mandate. Ohafia: Mekaria Organization.

Ncha, Gabriel (2010) Application of some aspects of JeanPaul Sartre's Existentialist Philosophy to the Niger Delta Problem" An unpublished Ph.D Dissertation, Presented to Graduate School, Unical.

Okoh, Peter (2007) The place of ethnicity in the struggle for self-determination of the south-south zone of Nigeria. In Bassey and Oshita, (eds) conflict resolution, identity crisis and Development in Africa. Lagos: Matthouse Press.

Paasewe, Sylvester Vaanii (2003) Neocolonialism in Africa, Liberia: The last Target Calabar: Uptrike Press.

Sartre, Jean-Paul (1993) Being and Nothingness Trans. Hazel E. Barnes. London: Rutledge.

Sartre-Jean-Paul. Existentialism is a Humanism. Reprinted in Walter Kaufmann, Existentialism from Dostoevsky to Sartre. New York: the world Publishing Company.

Ucheaga, D. N. (2009) Sustainable Development and the ethnic minority Question in Nigeria. Abibisem: Journal of Africa culture and civilization. Vol. 2, 2009. PP. 107124.

Udeme, Ekpo (2004) The Niger Delta and Oil Politics. Lagos: International Energy Communication.

William, Idowu. Citizenship Status, Statehood Problems and Political Conflict: The case of Nigeria. Nordic Journal of African Studies. 8 No 2, 1999. P. 73-88. 